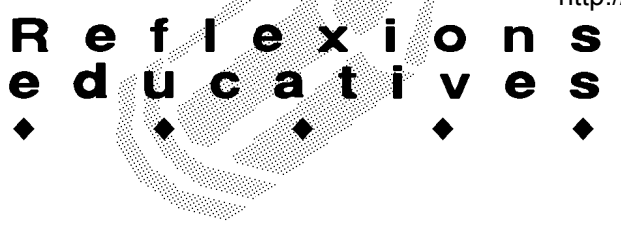

http://www.revistes.publicacionsurv.cat/index.php/comeduc

\title{
ELS LLIBRES ESCOLARS FRANQUISTES
}

\author{
Montse López Morales i Mercè Martí Pla. \\ Alumnes de 3r curs de l'Ensenyament de Mestre en Educació Especial. Tarragona.
}

L'article que presentem és una síntesi del treball realitzat a l'assignatura Didàctica de la Història Local i Comarcal, impartida pel professor Antoni Gavaldà al curs 199596 a la Facultat de Ciències de l'Educació i Psicologia (URV). El treball es va basar en l'estudi de quatre llibres escolars, publicats durant l'època franquista. En aquell moment els llibres escolars no s'entenien com s'entenen actualment, ja que un sol llibre cobria totes les àrees de coneixement a treballar, i rebia el nom d'enciclopèdia. De les quatre que es van analitzar, tres no duien data d'impressió, tot i que és possible que es publiquessin pels volts del anys cinquanta. A l'apartat de referències bibliogràfiques hi ha la relació de llibres analitzats.

La línia de treball que es va seguir fou: contextualitzar certs aspectes del llibre; recollir frases i expressions textuals significatives sobre certs aspectes, i extreure'n unes conclusions, a la llum de les aportacions curriculars actuals; contrastar el discurs històric de l'ahir amb el d'avui; i finalment relativitzar la càrrega política de libres amarats d'ideologia.

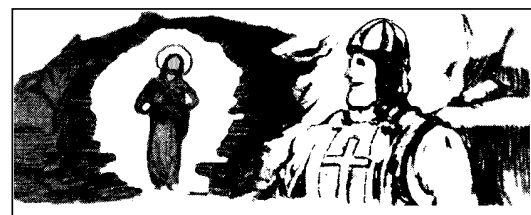

LA AYUDA DE LA VIRGEN

Cuando ya llevaban los godos muchos años viviendo en España, los moros derrotaron a su rey $\mathrm{D}$. Rodrigo en la batalla de Guadalete, y comenzaron a hacerse los amos de los pueblos españoles.

Como los moros prohibían a las gentes rezar a la Virgen María, y esto no podían consentirlo los españoles, el rey Don Pelayo esperó a los moros en las montañas de Asturias.

Y, ayudado por Nuestra Señora, les derrotó completamente en la memorable batalla de Covadonga.

La Virgen protege y ayuda siempre a los españoles cuando luchan contra los enemigos de nuestras creencias.

Imatge i text extret d'un llibre franquista sense cronologia concreta, reproduït a: Quaranta anys sense llibertats. El Franquisme, d'Antoni Gavaldà. Editorial Graó. Barcelona. 1994.
Els quatre llibres quasi bé tracten els mateixos temes. La religió hi té un pes important, ja que encapçala cada llibre amb sentències i dictats d'on és el bé, amb tons d'infal-libilitat. Els temes sobre formació política hi són incorporats, circumstància que implica que hi ha una intenció formativa per part del règim de l'època. Ens va sobtar que hi haguessin temes separats per raó de sexes, creant diferències notables entre l'educació dels nois i de les noies.

El treball va analitzar diferents aspectes, però els que ens han semblat més significatius són: el tractament que li dóna a la Segona República, l'enfocament de la guerra civil i el "Movimento Nacional".

\section{La Segona República}

En els llibres investigats, en general no hi ha temes dedicats de forma exclusiva a la Segona República i les referències que s'hi fan són des d'altres temes propers en el temps. En el moment que es parla d'aquest període històric, hi ha una forta crítica a la tasca renovadora dels republicans, ja que segons els autors trencaren el conservadorisme dretà d'Espanya, tot jugant amb el sentiment patriòtic i religiós: "(..) de la conspiración de los partidos extremistas y agitadores que querían acabar con las bases permanentes de nuestra tradicionalidad religiosa y patriótica..."

S'ironitza sobre els fins del govern republicà en allò que fa referència a la reforma, al progrés, a la democràcia... titllant-los d'anàrquics, ja que: “(..) ha llevado a España a la anarquía y ha puesto en trance de perecer salvándose, y con ella la civilización cristiana, gracias al glorioso alzamiento de/ $36 . . . "$

D'altra banda, la manipulació resulta dura, ja que tots els llibres relacionen el tema de la Segona República amb I'exili d'Alfons XIII, culpabilitzant els republicans de la inestabilitat monàrquica.

\section{La guerra civil}

El tractament de la guerra civil sorprèn per la poca o nul.la atenció que se li dedica. L'única referència que s'hi fa és respecte al "triunfo nacional". En cap moment es parla de qui van ser els veritables revolucionaris. De la mateixa manera es barreja la religió catòlica amb la pàtria, ja que es diu: 


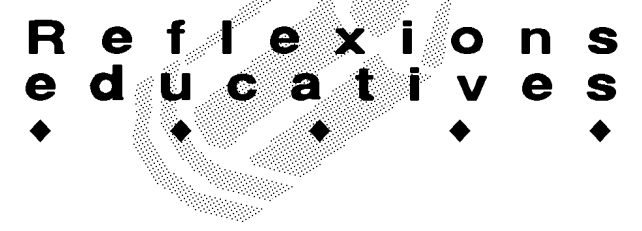

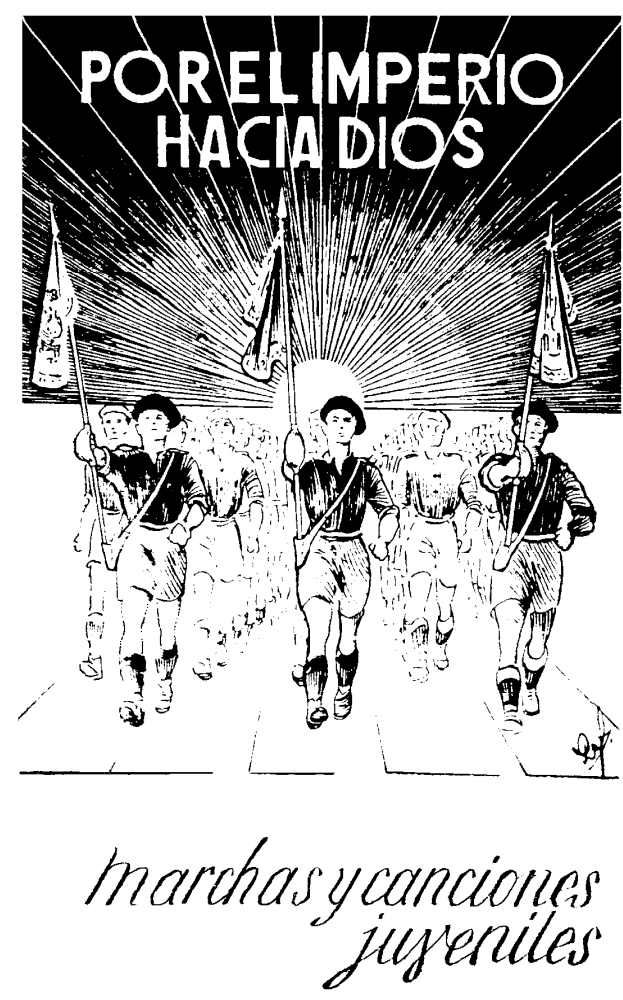

Portada d'introducció a les cançons juvenils, del Cancionero juvenil, d'ús obligat als centres d'ensenyament. L'autor és el pare marista $\mathrm{H}$. Manuel Rodríguez. Editat pel "Frente de Juventudes", l'any 1947.

"derrotados los rojos (...) ha vuelto el pueblo español a poder manifestar sus sentimientos católicos, ha vuelto España a sentirse capaz de emprender rutas imperiales", aspecte, aquest darrer, emparentat amb idees feixistes.

\section{El "Movimiento Nacional"}

Sobre el "Alzamiento Nacional" vàrem comprovar que es justifiquen les causes per les quals hi va haver la sublevació contra el govern republicà (intervenció sempre anomenada el "Glorioso Alzamiento"). L'expressió que podria sintetitzar tot això són frases d'aquest tipus: "para salvar a España y a la civilización cristiana en peligro", "no era posible dejar que la Patria continuase por más tiempo en manos de los criminales que la llevaban a la ruina, y a la esclavitud del comunismo ruso", etc.

Ens ha sobtat la manipulació de voler convèncer els escolars en el sentit d'estar d'acord amb l'aixecament, ja que, segons els llibres, va ser espontani i popular perquè va ser seguit "de una manera entusiasta y decidida por la mayoría del pueblo español",; i alhora justa perquè no es va lluitar per cap partit ni classe social, sinó "por el bien supremo de España y los españoles".

L'única base per a la justificació va ser emparar-se en la religió i en el sentiment patriòtic, aspectes amb els quals la manipulació arribava a fites quasi grotesques. Els ideals pels quals es movien eren buscar "la España Una, Grande y Libre".

\section{L'ensenyament franquista}

Tot i que aquestes apreciacions són constatades, ens vam adonar que els programes educatius del moment, reflectits en els textos analitzats, eren manipulats en dues direccions estretament lligades: d'una banda, la religió catòlica, i per l'altra, enaltir el sentiment patriòtic. El règim exercí una repressió sobre el sistema educatiu, tot intentant apropar les dues espanyes sota paràmetres de solidaritat, tolerància $\mathrm{i}$ comprensió, remarcant, però, qui eren els guanyadors. Els programes i materials escolars estaven supervisats pel Ministerio de Educación i sota la supervisió dels organismes en matèria de formació patriòtica i per l'Església catòlica. Es va abandonar així tota la renovació pedagògica que es va dur a terme durant l'època republicana.

L'ensenyament passà a ser controlat pel règim franquista. Fins i tot per augmentar aquesta pressió ideològica s'implantà l'assignatura de "Formación del Espíritu Nacional". Aquesta formació política només pretenia inculcar la ideologia falangista, parlant de les obligacions envers la pàtria. A través d'aquest fet educatiu, marcaven unes pautes de control i repressió sobre la societat, en infants i joves en edat de seguir un aprenentatge pautat $i$ correlatiu. La història es convertí en una epopeia de glòries hispanes imperials.

La figura de Franco als llibres escolars es destacà molt. El presentaven com un heroi que dugué l'Estat espanyol a la "liberación". S'aprofitava qualsevol excusa per realçar la seva carismàtica i forta personalitat, la seva feina "tan gloriosa". Era considerat el "salvador de la Patria".

\section{Conclusions}

A través d'aquesta breu reflexió en la recerca ens hem adonat que alguns problemes actuals encara provenen d'aquella època fosca. Però, sobretot, hem vist com la història a l'escola era manipulada per tal de "formar" persones sense afany crític. Tot eren relats dels (i sobre els) guanyadors d'una guerra, els quals s'havien d'aprendre mecànicament, amb la qual cosa la història es transformava en un puntal d'adoctrinament mancat de la finalitat que havia de tenir: formar per pensar i pensar per actuar.

\section{Referències bibliogràfiques}

ÁlVAREZ, A. Enciclopedia Intuitiva, Sintética y Práctica. Iniciación Profesional. Editorial Miñón S.A. Valladolid. 1963.

FERNÁNDEZ, A. Enciclopedia Práctica. Grado Elemental. Editorial Miguel Salvatella. Barcelona.

Enciclopedia Estudio. Libro verde.

Nueva Enciclopedia Escolar. Grado Tercero. Editorial Hijos de Santiago Rodríguez. Burgos. 